\title{
A FEBRASGO e o Ensino da Ginecologia e da Obstetrícia
}

A FEBRASGO, há muito, tem-se preocupado com a qualidade da formação dos ginecologistas e obstetras. A Comissão de Residência Médica da FEBRASGO, em parceria com a Comissão Nacional de Residência Médica do Ministério da Educação e do Desporto, têm trabalhado e assessorado os Serviços de Residência Médica, em parceria com as Federadas, sempre que solicitada.

A integração, para troca de mercadorias e de prestação de serviços entre Argentina, Brasil, Paraguai e Uruguai, criou uma nova realidade, o Mercado Comum do Sul - O MERCOSUL. A FEBRASGO, pensando na queda das restrições para o trabalho médico, entre os povos que firmaram o tratado, à partir de 2001, juntamente com as Federadas e Sociedades dos demais países, está trabalhando para uniformizar a formação do especialista que atuará no MERCOSUL.

A FEBRASGO também está preocupada com o ensino da ginecologia e da obstetricia no curso curricular, pois sabemos que grande contigente dos médicos, desse imenso Brasil, não tendo acesso às Residências Médicas, são generalistas e praticam a medicina como um todo, e por isso precisam receber informações e treinamento durante o curso que os possibilite realizar atendimentos e procedimentos médicos com eficiência.

\section{A Diretoria}

